\title{
The changing incidence of gonadal germ cell tumours
}

\author{
RG Wright ${ }^{1, *}$ and R Panchal ${ }^{1}$ \\ ${ }^{1}$ Faculty of Health Science and Medicine, Bond University, Gold Coast, Queensland 4229, Australia
}

\begin{abstract}
Ovarian and testicular germ cell tumour incidence has been studied fairly extensively. An increasing number of male reproductive disorders including an increasing incidence of testicular germ cell tumours have been identified. The aetiology is attributed to intrauterine exposure to environmental agents affecting the foetal testis. It has been speculated that oestrogens may be responsible for some of these changes. The incidence of female gonadal germ cell tumours has not been closely investigated. A recent literature review comparing incidence of ovarian and testicular germ cell tumours in the same populations has been carried out. 84 published studies were identified and five studies included results for incidence of contemporaneous male and female gonadal germ cell tumours in the same population. In all studies there was a significant increase in incidence of male malignant gonadal germ cell tumours. In all studies there was no significant increase in female malignant gonadal germ cell tumours. The explanation for these differences remains complex. We suggest that there is selective apoptosis in the developing ovary which could prevent the development of malignant germ cell tumours in the foetal ovary and this does not occur in the developing testis.
\end{abstract}

Keywords: gonadal germ cell tumour; testicular germ cell tumour; ovarian germ cell tumour

\section{Background}

Skakkebaek and others have highlighted an increasing number of male reproductive disorders including an increasing incidence of testicular germ cell tumours, mainly in Europe [1]. They attribute the aetiology to intrauterine exposure to environmental factors affecting the foetal testis. Sharpe and Skakkebaek speculated that oestrogens may be responsible for some of these changes [2]. The analysis of the increasing incidence of male gonadal germ cell tumours has been extensively studied but the comparison with female gonadal germ cell tumours has not been closely investigated. This may be partially related to the lower incidence of malignant gonadal germ cell tumours in females. This review considers the small numbers of studies examining the incidence of malignant gonadal germ cell tumours in contemporary populations.

\section{Methods}

This report is based on a Medline search of medical literature commencing in 2000 until 2016. Key search words used were "germ cell tumor incidence, ovary germ cell tumor incidence, testis germ cell tumor incidence and gonad germ cell tumor incidence". All published articles reporting incidence of ovarian and testicular malignant germ cell tumours were identified. 84 articles were found. Reports including both malignant ovarian and testicular tumours with incidence reported over at least 10 years for both ovarian and testicular malignant germ cell tumours were considered in more detail. Five studies met this criterion. Most studies identified only included testicular tumour incidence. Three reports included data of a shorter duration than 10 years. The incidence of male and female gonadal germ cell tumours at the commencement and completion dates of the studies was recorded. The results were tabulated and compared.

\section{Results}

84 published studies between 2000 and 2016 were identified and five studies [3-7] included results for incidence of contemporaneous male and female gonadal germ cell tumours in the same population. All of these studies excluded or separately reported extragonadal germ cell tumours. All studies excluded non gonadal tumours or reported the results separately. In all the studies the

*Corresponding author: Gordon Wright, Faculty of Health Science and Medicine, Bond University, Gold Coast, Queensland, Australia. Email: gwright@bond.edu.au

Received 20 December 2017 Revised 26 January 2018 Accepted 10 February 2018 Published 24 February 2018

Citation: Wright RG, R Panchal. The changing incidence of gonadal germ cell tumours. J Mod Hum Pathol. 2018; 3(2):4-6. DOI: 10.14312/23976845.2018-2

Copyright: @ 2018 Wright RG, et al. Published by NobleResearch Publishers. This is an open-access article distributed under the terms of the Creative Commons Attribution License, which permits unrestricted use, distribution and reproduction in any medium, provided the original author and source are credited. 
testicular malignant germ cell tumour incidence was greater than ten times the incidence of ovarian malignant germ cell tumours. In all studies there was a significant increase in incidence of male malignant gonadal germ cell tumours over a ten-year period. In all studies there was no significant increase in female malignant gonadal germ cell tumours and in three studies there was a decline in incidence during the study. The studies identified are listed with details in Table 1. They demonstrate a range of studies reported from many regions including the UK, Germany, Finland, Australia and the USA. No reports from Africa met the criteria for the search. The various studies identified were carried out over different durations. The shortest was 10 years [5] and the longest 39 years [7]. The data collected in the studies ranged from 1960 to 2011. All of the studies overlapped to some extent. The total number of germ cell testicular and ovarian germ cell tumours and incidence of malignant testicular germ cell tumours at the commencement and completion of the studies are listed in Table 1. The incidence of malignant ovarian cell germ cell tumours at the commencement and completion of the studies is listed in Table 1.

Table 1 Data collection of number of malignant testicular, and ovarian germ cell tumours and incidence of gonadal germ cell tumours in males and females with study period exceeding 10 years.

\begin{tabular}{|c|c|c|c|c|c|c|c|c|c|}
\hline 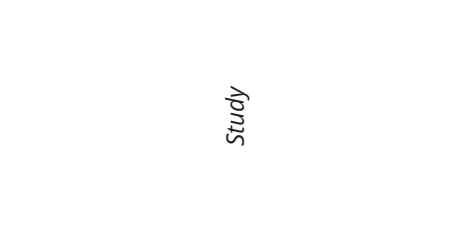 & 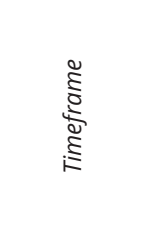 & 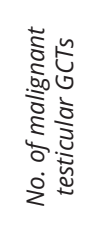 & 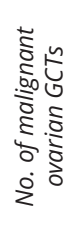 & 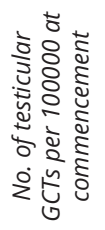 & 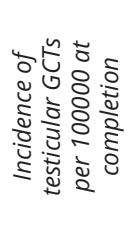 & 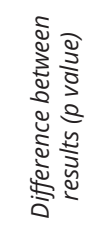 & 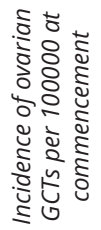 & 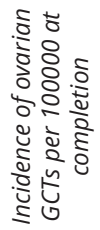 & 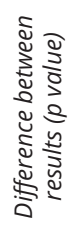 \\
\hline $\begin{array}{l}\text { Van Leeuwen et al., Cancer Epidemiol. } \\
\text { 2016; 43:15-21. }\end{array}$ & $1982-2011$ & 16204 & 1075 & 5 & 7.5 & $P<0.01$ & 0.4 & 0.4 & ns \\
\hline $\begin{array}{l}\text { Paunaiho et al., Cancer Causes Control. } \\
\text { 2012; 23(12):1921-1927. }\end{array}$ & $1973-2002$ & 2557 & 232 & 3.8 & 8.5 & $P<0.01$ & 0.2 & 0.28 & ns \\
\hline $\begin{array}{l}\text { Rusner et al., Cancer Epidemiol. 2013; } \\
\text { 37(4):370-373. }\end{array}$ & $1998-2008$ & 16170 & 331 & 4.5 & 8.9 & $P<0.01$ & 0.21 & 0.13 & ns \\
\hline $\begin{array}{l}\text { Strang et al., Int J Androl. 2012; } \\
\text { 35(4):616-625. }\end{array}$ & $1973-2007$ & 11468 & 545 & 6.2 & 8.5 & $P<0.01$ & 0.33 & 0.31 & ns \\
\hline Moller et al., APMIS. 2003; 111(1):43-46. & 1960-1999 & 7910 & 453 & 2.1 & 5.2 & $P<0.01$ & 0.15 & 0.18 & ns \\
\hline
\end{tabular}

Abbreviations: GCTs = germ cell tumours.

In all studies testicular tumour incidence predominates. There is a significant increase in incidence of testicular germ cell tumours in all studies $(p<0.01)$. No significant increase in incidence of ovarian malignant germ cell tumours is seen. Data on specific germ cell tumour types was not reported in all of the studies. No data on specific germ cell tumours could be extracted but three studies noted that seminoma and dysgerminoma were the most prevalent tumour types in their series $[3,4,7]$.

\section{Discussion and conclusion}

This literature review identified five published articles between 2000 and 2016 with reports on incidence of malignant ovarian and testicular germ cell tumours in the same population over at least a 10-year interval. 84 published articles on incidence of ovarian or testicular malignant germ cell tumour incidence were identified and five articles met the criteria selected. The studies were on populations in the USA, UK, Germany, Australia and Finland. All five studies demonstrated a significant increase in incidence of malignant germ cell tumours in males and no increase in females. Studies excluded from the study usually considered only male or female germ cell tumour incidence or were of duration less than 10 years. No data on specific germ cell tumour types could be extracted but three studies noted that seminoma and dysgerminoma were the most prevalent tumour types in the studies [3, $4,7]$. Increase in testicular seminoma incidence is likely to explain most of the increased incidence in males. The explanation for this difference remains complex because the morphology of testicular seminoma and ovarian dysgerminoma is similar [9]. Several explanations for this difference have been suggested. The dominant explanation centers around the relationship to birth-cohort [8]. This was noted particularly with increase in incidence of seminoma. This suggests significant events are likely to have taken place in-utero. Skakkebaek has also noted coexisting abnormalities in European populations with lowered quality of seminal fluid and increased incidence of hypospadias [1]. A less likely explanation is that potential risk factors have increased over the duration of the studies. The explanation for no significant increase in incidence of germ cell tumours in females has not been widely considered. Cell loss of germ cell precursors in the ovary occurs in midtrimester onwards [10]. The control of these critical events is not fully understood in the developing human ovary. It is likely that controlled apoptosis in the developing ovary may prevent development of ovarian malignant germ cell tumours in childhood and young adult life. This would be consistent with the birth-cohort effect being restricted to male foetuses and would provide an explanation for the complex data. Comparative investigations on developing gonads may allow this possibility to be clarified.

\section{Conflicts of interest}

Authors declare no conflicts of interest.

\section{References}

[1] Skakkebaek NE, Raipert-DeMeyts E, Buck Lewis GM, Toppari J, Andersson AM, etal. Male reproductive disorders and fertility trends. Physiol Rev. 2016; 96(1):55-97. 
[2] Sharpe RM, Skakkebaek NE. Are oestrogens involved in falling sperm cell counts and disorders of the male reproductive tract? Lancet. 1993; 341(8857):1392-1396.

[3] Van Leewen MT, Gurney H, Turner J, Turner SL, Pearson SA, et al. Patterns and trends in the incidence of germ cell tumours in Australia, 1982-2011. Cancer Epidemiol. 2016; 43:15-21.

[4] Pauniaho SL, Salonen J, Helminen M, Vettenranta K, Heikinheimo M, et al. The incidences of malignant gonadal and extragonadal germ cell tumors in males and females: A population-based study covering over 40 years in Finland. Cancer Causes Control. 2012; 23(12):1921-1927.

[5] Rusner C, Trabert B, Katalinic A, Kieschke J, Emrich K, et al. Incidence patterns and trends of malignant gonadal and extragonadal germ cell tumors in Germany, 1998-2008. Cancer Epidemiol. 2013; 37(4):370373.

[6] Stang A, Trabert B, Wentzensen N, Cook MB, Rusner C, etal. Gonadal and extragonadal germ cell tumors in the United States, 1973-2007. Int J Androl. 2012; 35(4):616-625.

[7] Moller $\mathrm{H}$, Evans $\mathrm{H}$. Epidemiology of germ cell tumours in males and females. APMIS. 2003; 111(1):43-46.

[8] McGlynn KA, Devesa SS, Sigurdson AJ, Brown LM, Tsao L, et al. Trends in the incidence of testicular germ cell tumors in the United States. Cancer. 2003; 97(1):63-70.

[9] Nogales FF, Dulcey I, Preda O. Germ cell tumors of the ovary: An update. Arch Pathol Lab Med. 2014; 138(3):351-362.

[10] Fulton N, Martins da Silva SJ, Bayne RA, Anderson RA. Germ cell proliferation and apoptosis in the developing human ovary. J Clin Endocrinol Metab. 2005; 90(8):4664-4670. 